\title{
Creating Organisational Strength from Operationalising Restrictions: Welfare Non-profit Organisations in the Russian Federation
}

\author{
Jo Crotty ${ }^{1} \cdot$ Sergej Ljubownikow ${ }^{2}$ (D)
}

Accepted: 28 August 2020/Published online: 15 September 2020

(C) The Author(s) 2020

\begin{abstract}
The work of non-profit organisations (NPOs) in non-democratic country contexts tends to be judged on their contribution to the democratisation process rather than the activities they undertake. This neglects the potential impact NPOs have on societies within such contexts. In this study, we highlight that NPOs can influence public policy deployment in the Russian Federation even if they cannot affect public policy itself. By operationalising the very restrictions placed upon them, NPOs use their relationships with the state to effect change within their immediate environment and scope of their operational remit, even if they cannot hold authorities to account or influence policy development. The key to this is strong organising capabilities and engagement with the Russian public. We reflect on the implications of our findings to the understanding of civil society development and NPOs in Russia and in other similar non-democratic contexts.
\end{abstract}

\section{Keywords Hybrid regimes · Russia $\cdot$ NPOs}

Civil society and its agents have seen their space for activity limited across both democracies and other political regimes (Anheier et al. 2019; Bloodgood et al. 2014). In particular, hybrid political regimes have attempted to shape a civil society sector that aligns with the regime's needs

Sergej Ljubownikow

s.ljubownikow@sheffield.ac.uk

Jo Crotty

Crottyj@edgehill.ac.uk

1 Institute for Social Responsibility, Edge Hill University, Ormskirk, Lancashire L39 4QP, UK

2 Sheffield University Management School, Conduit Road, Sheffield S10 1FL, UK
(Hale 2010; Karl 1995; Owen and Bindman 2017; Wilde et al. 2018). Hybrid regimes are also referred to as participatory authoritarian (Mainwaring 2012; Owen 2018; Xiaojun and Ge 2016). They combine characteristics of participatory democratic governance such as regular elections with authoritarian tendencies such as a dominant party of power and/or restrictions on civil liberties such as limits on press freedoms and/or limits on freedom of association (Diamond 2002; Wigell 2008). In line with such tendencies, hybrid regimes seek to align civil society with their own goals, through restricting the public sphere and setting clear boundaries on the activities civil society agents, including non-profit organisations (NPOs), can pursue (Karl 1995; Wilde et al. 2018). Thus, hybrid regimes tend to focus on shaping the scope of NPOs activities in particular of those that can challenge governance arrangement. A key aspect to this is restricting organisational engagement in activities that in the literature would fall under the advocacy umbrella (Almog-Bar and Schmid 2014) and which could be termed as big 'P' politics; that is to say, activity aligned to party politics, (shaping and influencing) policymaking, or attempts to hold the state to account (Hale 2010; Richter and Hatch 2013; Shapovalova 2015; Spires 2011). This also enables hybrid regimes to demark what is considered to be 'right' and 'wrong' civil society (Daucé 2015).

Despite these restrictions, NPOs continue to play a role in governance arrangements within hybrid regimes (Guo and Zhang 2014). Hence, hybrid regimes encourage some type of NPOs, frequently via resource provision to provide welfare services (or what could be considered the right sort of civil society). However, to provide these services also means that NPOs have to demonstrate their relevant organisational strength and engage in what could be termed small 'p' politics. Small 'p' politics requires engagement 
with constituencies and clients as well as or broader public and building and managing of networks that help to navigate their operating environment, help to determine how policy is deployed even if the policy itself cannot be influenced. As a result, NPOs become 'apolitical helpers' (Kulmala 2016, p. 200). Similarly, Ljubownikow and Crotty (2016) observe that NPOs in the Russian Federation strategically frame themselves as apolitical to make it easier to interact or even become part of state structures. This, in turn, gives them access to resources and allows them to exert influence over public policy deployment. Therefore, despite what seems to be rather clear boundaries for NPO activity (i.e. 'don't be Political'; engage in the 'right' type of civil society activity), their welfare provision role does give such organisations potential political (small 'p') power. Riley and Fernandez's (2014) propose that path-dependent influences of past regime arrangements shape civil society. Specifically, they highlight how the past impacts civil society arrangements in post-dictatorial contexts, many of which are now characterised as hybrid regimes (Riley and Fernández 2014). In such contexts, NPOs might lack autonomy from the state to be Politicalto shape policy, either locally or nationally, to challenge the status quo, or effectively hold state authorities to account. But they still have organisational strength, that is to say, political power to influence how policy is deployed and to negotiate the associated networks therein. As such, they can still contribute to society both by providing welfare services (often their core mission) and also by facilitating good (if not necessarily democratic) governance (Riley and Fernández 2014).

These considerations lead to our research question; how do NPOs in hybrid regimes use 'mundane' day-to-day activity of providing (welfare) services to affect change in their immediate environment? To explore this question, we focus on NPOs organisational strength and whether it provides them with small 'p' political power.

To examine this, we use an activity lens. An activity lens enables micro-level focus and aims to explore what organisations do, rather than what they ought to be doing based on certain normative conceptions (Cohen and Arato 1994). This approach also enables us to link such microlevel explanations to macro-phenomena (Sivunen and Putnam 2020; Whittington 2006). Given our focus on the role of civil society in a hybrid regime (i.e. understanding how NPOs act within this institutional context) and whether and how NPOs might activate the citizenry [i.e. getting individuals to do civil society thus to engage with them (Vorbrugg 2015)], in this paper, we are primarily concerned with external activities of such organisations. We draw on Riley and Fernández (2014) who suggest the need to distinguish between organisational strength and organisational autonomy. The post-dictatorial context of Italy and
Spain indicates that democratic reforms do not automatically lead to NPO autonomy and that they can remain heteronomous (i.e. subject to external control) within such contexts (Riley and Fernández 2014). However, organisational strength might provide NPOs with some basis to engage with the state as part of small ' $p$ ' politics thru access to elites and their associated resources, and the deployment of such networks, improving the experience of their constituents and governance within a set legislative context as a result.

To examine organisational strength and heteronomy in more detail, we study NPOs in the Russian Federation. We have selected the Russian Federation due to the hybrid nature of its regime (Hale 2010), because Russian civil society has historically been characterised as weak (i.e. lacking organisational strength) (Henry and Sundstrom 2006); NPOs are seen to have squandered their opportunity to build a functioning third sector (i.e. influencing governance arrangements and activities), following the Soviet Union's collapse nearly 30 years ago (Robertson 2009). However, more recently some researchers have observed more dynamism amongst Russian civil society actors (Bogdanova et al. 2018; Skokova et al. 2018; Tarasenko 2018), but still, consider their capacity vis-à-vis democratising Russia's authoritarian regime as limited (Berg-Nordlie and Bolshakov 2018; Flikke 2018; Ljubownikow and Crotty 2016; Moser and Skripchenko 2018; Owen 2015; Owen and Bindman 2017; Tysiachniouk et al. 2018). Further, the Russian Federation and its attempt to control or limit the scope of civil society agents is also mirrored in other hybrid regimes and authoritarian contexts (Richter and Hatch 2013; Spires 2011; Xiaojun and Ge 2016). This makes the Russian Federation an illuminating context to explore issues of organisational strength and heteronomy. Focusing on Russian NPOs enables us to explore the specificities of the Russian Federation and gain some potential representative insights about hybrid regimes and civil society and organisations therein. This enables our paper to broaden the understanding of civil society and its arrangements in contexts hostile to its existence. In presenting our insight, we first provide a concise overview of research on Russian civil society. We then present our research study before illustrating our key insights. Our paper finishes with a discussion and conclusion of our insights.

\section{Civil Society in the Russian Federation}

The extant literature portrays Russian NPOs as organisationally weak and heteronomous confirming the negative outlook for Russia civil society illustrated by Linz and 
Stepan ${ }^{1}$ back in 1996 . The majority of past and more current studies of Russian NPOs highlight an institutional context hostile to NPOs (Crotty et al. 2014; Daucé 2015; Flikke 2018; Henderson 2008; Ljubownikow and Crotty 2014; Salamon et al. 2015; Skokova et al. 2018; Tarasenko 2018). Much of this past research has focused on the limits the institutional context placed on NPO activities, namely revenue controls and registration requirements (Crotty et al. 2014; Daucé 2015; Robertson 2009; Salamon et al. 2015), restrictions on interaction with organisations abroad (Skokova et al. 2018), and limits on rights to protest and assembly (Johnson and Saarinen 2011; Ljubownikow and Crotty 2016; Richter and Hatch 2013). At the same time, research has also highlighted deficiencies at the organisational level and presents Russian NPOs as parochial, disengaged from their constituencies, and a broader public that views them as irrelevant and untrustworthy (Chebankova 2009; Crotty 2006; Henderson 2002; Henry 2006; Spencer and Skalaban 2018).

Research also highlights that many Russian NPOs are reliant on the state to ensure survival, and as a result present them as being nationalised, emasculated, licensed, and/or agents of the state (Ljubownikow et al. 2013; Richter and Hatch 2013; Robertson 2009). In turn, Russian NPOs are unable to hold the state to account in a meaningfully way and contribute little to democratisation (Ljubownikow and Crotty 2017). However, there are notable exceptions to the above. For example, research on the women's rights movement has indicated that although organisations are limited when it comes to democratisation, they can still have some societal impact (Hemment 2004, 2007). Similarly, research focusing on NPOs providing welfare services paints a brighter and more colourful picture in particular with regard to organisational strength and advocacy (Henry 2012; Ljubownikow and Crotty 2016; Pape 2018; Skokova et al. 2018). Such organisations have been able to carve out a distinct space for social if not Political activity (Skokova et al. 2018).

Nonetheless, Russia's hybrid regime continues to restrict what NPOs can do. The Russian state has continued with legislative developments to ensure heteronomous control of NPOs (Flikke 2018; Ljubownikow and Crotty 2014; Moser and Skripchenko 2018) as well as creating competition for resources (Daucé 2015; Fröhlich and Skokova 2020; Ljubownikow and Crotty 2017; Salamon

\footnotetext{
1 The assumption was that because of the totalitarian nature of the Soviet Union, the civil society sector in the post-Soviet space would be characterised by associational weakness (Linz et al. 1995; Linz and Stepan 1996). Early studies of the states of the Former Soviet Union did also illustrate this (Howard 2002). Registered association numbers in Russia, which tend to fluctuate around 200,000-250,000 organisations (Skokova 2017), does seem to support this associational weakness idea.
}

et al. 2015; Skokova et al. 2018). In turn, this has led NPOs to become an integral part of the state's welfare provision, through their engagement and participation in social contracting schemes (Benevolenski and Toepler 2017; Tarasenko 2018). However, authors have observed that the welfare-oriented action of NPOs has been able to challenge some practices associated with public policy decisions and influenced how public policy has been deployed at a regional and local level (Berg-Nordlie and Bolshakov 2018; Ljubownikow and Crotty 2016). This, in turn, suggests that despite the restrictive nature of Russia's institutional context which constrains opportunity for political protest or to challenge the state (Daucé 2015; Henry 2012; Ljubownikow and Crotty 2016; Tysiachniouk et al. 2018), NPOs have the ability to organise and thus do have organisational strengths.

The collaboration and close integration between the Russian state and welfare NPOs (i.e. the right type of organisations) can trace its roots to the socialist self-management system of the Soviet Union (Vetta 2018). Despite the emergence of many social welfare organisations during the 1990s (Cook 2007; Fröhlich 2012; Jakobson and Sanovich 2010; Kulmala and Tarasenko 2016), recent insights suggest that the most effective social welfare NPOs are now those with the right combination of capabilities and resources to 'do' good for their constituencies and the ability to navigate their networks and relationships with relevant state authorities (Bogdanova et al. 2018; Skokova et al. 2018; Tarasenko 2018). It is fair to assume that welfare NPOs will have always had capabilities to organise and thus organisational strength, but that the institutional context of the 1990s was not conducive to leverage those. However, in the current institutional context of constraint space for civil society actors and legacies of welfare NPOs working with the state, it now enables such organisation to use their day-to-day activities (i.e. organisational strength) to advance relevant issues within the structure of the state. This organisational strength has put key individuals in charge of welfare NPOs at the intersect between the state and civil society and thus in a position to operate spaces of power (Ljubownikow and Crotty 2017). In turn, this highlights that NPOs might have the potential to instigate changes working within the regime and its confines (Ljubownikow and Crotty 2016; Owen 2015; Owen and Bindman 2017). Thus, in this study, we draw on data collected from a subsection of welfare focused NPOs, namely those addressing on health-related issues (hNPOs) to explore if such social oriented organisations can use their day-to-day activities to demonstrate organisational strength. We outline our research study below. 


\section{The Research Study}

In order to address our research question of how NPOs in hybrid regimes use their day-to-day activity of providing (welfare) services to potentially effect change, our data collection process aimed at establishing the modus operandi of hNPOs. To encourage hNPOs to illustrate what they do, we operationalised semi-structured interviews with key decision-makers as a key data collection technique. We supplemented this, also to triangulate respondents' illustrations, with observations. One of the researchers spent an average working week with each organisation. Observations and any informal conversations during this period were recorded in an extensive daily research diary (Miles and Huberman 1999). Hence, this qualitative approach enabled us to explore how key decision-makers portrayed their activities and how they saw them being operationalised both in terms of demonstrating organisational strength as well as political engagement (which as we illustrate in our findings section was mainly that of the small 'p' kind).

We carried out 24 interviews across 12 organisations. We focused on organisations located in regional capital cities outside the urban centres of Moscow and St. Petersburg as they are said to be unrepresentative of most of Russia (Javeline and Lindemann-Komarova 2010). Our study focused on the two regional centres of Perm and Samara (see 'Appendix A'). Perm city is the regional capital of the Permsky Kray (Perm Region), which is dominated by extractive industries such as oil. The city of Samara is also the regional capital to Samarskaya Oblast (Samara Region), which is a centre for manufacturing, in particular, automotive (Federal State Statistics Service 2010). We focused on organisations in regional capital cities where they were greater in number, and because regional capitals exhibit a concentration of state authorities and thus the potential of incidents of big ' $\mathrm{P}$ ' and/or small 'p' politics. We purposefully select organisations (Siggelkow 2007) based on their activities and objectives focusing on what is considered health/healthcare (zdravookhraneniye) issues in Russia and whether or not they understand themselves as obshchestvennyye organizatsii. Obshchestvennyye organizatsii can be translated to mean social or societal organisations-a widespread term both Russian NPOs and the Russian state use to describe NPOs both in law and colloquially (Spencer 2011). This approach also allowed us to create matched pairs, in the area of drug abuse/prevention and HIV/AIDS, disability, palliative care, and children living with cancer.

We drew on Gioia et al. (2013) when designing interview questions as well as using ethnographic interview techniques focusing our open-ended, non-leading questions on everyday organisational activities. Interviews were done with organisational leaders, as similar to the majority of Russian NPOs, and hNPOs in this study were small in size (only a few had any paid staff) with organisational cultures dominated by 'democratic centralism' - where the leader's ideas are adopted by full staff/member consent (Spencer 2011, p. 1080). Interviews were conducted in Russian and lasted on average $1 \mathrm{~h}$. Organisational documentation (publicly available as well as internal when supplied by organisations) was used to triangulate and validate interview responses and observations (Miles and Huberman 1999). Reflecting best practice for qualitative research, our data analysis process and data collection process overlapped, allowing for feedback from data analysis into the data collecting process (Gioia et al. 2013). To aid analysis, all interviews were transcribed and translated into English using a professional translation and transcription service. We began the analysis with open coding the interview transcripts, which produced using first-order codes (Gioia et al. 2013). Initial codes covered various specific activities organisations engaged in. As coding progressed iteratively, we consolidated these first-order codes into more abstract second-order themes elaborating organisational strength, organisational autonomy (Riley and Fernández 2014) and how and if hNPOs engage the wider public.

Complementing our data coding, we also engaged in constant a comparison to facilitate the identification of differences and similarities in data segments and respondents. For example, by comparing one organisation's account of what they do with that of others, we were able to detect similarities with regard to organisational strength, organisational autonomy, or engagement with the wider public. In presenting our findings, we draw on hNPOs main activities for structure and use excerpts from interviews as 'illuminating examples' (de Vaus 2001, p. 240) and supplementing it with observational notes from our research diary. ${ }^{2}$

\section{Findings}

Similar to other recent research (Moser and Skripchenko 2018; Skokova et al. 2018; Tarasenko 2018), we found Russian hNPOs to be dynamic and successful at carving out operating spaces for their welfare service provision. In extending this emerging insight, we also found that Russian hNPOs have been successful in influencing public policy deployment. However, echoing findings by Kulmala

\footnotetext{
2 To preserve the anonymity of respondents and their organisations, we use a numbered code. In this coding system, the prefix 1 is for Samara, and prefix 2 for Perm, with each hNPO then numbered 1-7 and interviews denoted as a for the first and $\mathrm{b}$ for the second.
} 
(2016), groups were very keen to stress that they did not engage in Politics (i.e. specific party politics, influencing policymaking, or holding the state to account) but focused on what they perceived and portrayed as apolitical activities. HNPO in our study thus submitted themselves to the heteronomous power of the state (Riley and Fernández 2014) and aligned themselves, and their activities with what they believed were the explicit or implicit requirements of the state (see Moser and Skripchenko 2018 for a similar insight amongst rights-focused organisations).

For hNPOs in this study, their day-to-day activities presented themselves as a good way to demonstrate their organising capabilities. In turn, this enabled hNPOs to promote themselves as viable partners with whom the state or its representations could engage in collaborative projects. This later engagement then opened up opportunities for hNPOs to engage in activities with potential effects on governance and governance arrangements, where they did not expect a negative response from the state or its representations (Tarrow 1989) or even perceived the state's receptiveness for input. Thus, to answer our research question as to how hNPO use their organisational strength, we explore what hNPOs do in more detail below.

\section{Core Service Provision}

As would be expected from organisations focusing on welfare services, hNPOs focused primarily on providing services that would improve their constituents' life experiences. To do so, hNPOs aimed to supply specialist services such as access to 'counselling' (2.1a; 2.4a), 'doctors...medication...moreover, social workers' (2.5a), 'rehabilitation equipment' (2.2a), 'legal services' (2.5a) and even organised immediate free medical treatment for a children's homeless shelter (Observation Notes). HNPOs were also working with underrepresented societal groups providing services aimed at 'giving them a chance' (1.1a) and an opportunity for constituents/clients to 'improve their skills' (2.7a) or develop new ones such as computer skills for pensionaries or conflict-solving skills for young offenders (Observation Notes from relevant events). Extending their service provision, hNPOs also engaged in activities to entertain their constituents such as 'outings for children' (2.2a; 1.2a), 'prom dances' (2.3b), 'puppet theatre, chorus and other activities', (2.7a), 'summer camps' (1.4a) and 'sporting competitions' (1.4b).

Another core part of their welfare activities for organisations in this study was what they termed 'educational' (1.4b) services. Other than the activities outlined above, which aimed at skill development of their constituencies, these services were aimed primarily at employees at state institutions that dealt with their constituency groups. At the core of these activities was the aim to improve the understanding within individuals and state structures of their constituents/clients, their needs and ultimately influence the practices used to engage with them. Here hNPOs in this study highlighted how they trained professionals from state institutions such as 'teachers' (2.3a), 'doctors' (1.3a), 'medical staff' (1.5a), 'social workers and school psychologists' (2.1a), in areas such as 'pain management' (1.3a) and 'drug prevention' (2.5a) and demonstrating them how to change operational-level practices within state institutions. To support the latter, respondents also emphasised that they engaged in co-production of material on 'the benefits of physical therapy' (1.2a), a leaflet highlighting 'legal issues [for those] working with foster families' (2.3a), or campaigns on drug prevention (2.1), which state institutions were able to use for their staff. Some hNPOs also highlighted how this had enabled them to act on behalf of the regional health authorities. Respondents illustrated that they distributed 'lubricants, condoms and disinfecting wipes' (2.5a) to sex workers, providing 'mobility equipment' and 'specialist employment services for the disabled' (1.1a), collecting and distributing 'school supplies' (2.3a), or operating an 'ex-offender support service' (2.5a). For hNPOs, this was evidence that they possessed organisational strengths that were valued by state authorities as well as constituency access (informal conversation with Chief Operating Officer during event observation, 2.5). HNPOs engaged in these educational services as well as taking on services usually provided by the state, can be seen as hNPOs leveraging this organisational strength into what can be characterised as small ' $p$ ' politics, that is to say, influencing practices of state institutions with regard to how they engage with their constituency and in effect improving governance.

The core service engagements illustrated by hNPOs in this study indicates an emerging mutual dependency between NPOs and the Russian state (Salamon et al. 2015). HNPOs have been able to leverage this mutual dependency (the state needs to address health issues and provide services, and hNPOs can organise and access marginalised societal groups) to engage in drug misuse prevention or working with ex-offenders and sex workers. Those are all areas that have traditionally been difficult to access for such organisations in the Russian Federation (Owen 2015; Titterton 2006). Russian hNPOs in our study used their organisational strength to contribute to Russian society by delivering their core services (that is fulfilling their mission), broadening the scope of those services, and improving how relevant state actors engaged with their constituencies. To some extent, this reflects path dependencies from the Soviet period, where social organisations, although under very strong heteronomous control of the state, did provide engagement opportunities for specific 
groups as well as their representations in local governance arrangements (e.g. the blind, the deaf, the disabled, and veterans (Fröhlich 2012; Kulmala and Tarasenko 2016; Thomson 2006). However, it also shows that the scope for hNPOs to engage in more than service delivery was limited. Instead, as we illustrate below, organisations focused on raising awareness of their core remit and engaging in humanitarian assistance.

\section{Awareness-Raising and Humanitarian Assistance}

Respondents considered both these types of activitiesawareness-raising and humanitarian assistance-as additional to their core engagements of providing welfare services, but as we show below, they also provided some basis for small 'p' politics. HNPOs aimed to combine the aim of raising awareness for themselves with that of increasing the understanding of their constituents/clients amongst the public. The description below by organisation 1.4 characterises the types of activities hNPOs engage in.

We organised an exhibition. We have provided all the information about where do the kids get treatment, about the survival rate, and rehabilitation process...We try to inform the public, get them interested in joining that [donor] register... we do this through publications in newspapers and magazines, or TV programs (1.4a)

Frequently, path-dependent social conventions formed a cornerstone to such engagements. Specifically, hNPOs aimed to draw on historical legacies and replicate Soviet traditions of commemoration by targeting awareness-raising events around days and events that formed an important part of everyday life in the Soviet period (Danilova 2016) such as 'Cosmonautics Day' (1.2a), 'International Childhood Cancer Day' (2.2a), International Women's Day, or International Labour Day. Often such events or days are either public holidays or still play an important role in commemorating the past, and thus, hNPOs aimed to capitalise on those by organising concerts $(2.2 \mathrm{a} ; 2.7 \mathrm{a})$ or award ceremonies $(2.3 \mathrm{a}, 1.1 \mathrm{a}, 1.2 \mathrm{a})$. Organisations organised concerts or award ceremonies as both celebrations of their work ['we just let everyone know that we exist' (2.2a)] but also to illustrate the 'plight' of their constituents/clients to the wider public ['a big event for all the kids graduating orphanages in Perm Krai' (2.3a)] and thus frequently invited local media (Observational notes from research diary). These events demonstrated how hNPOs were able to use their organisational strength (i.e. organising capability) and mobilise cultural legacies in order to raise awareness of their constituency (and themselves). Although this does not challenge the state or hold it to account, it does enable hNPOs to raise awareness of relevant issues with state authorities and the public more widely.

Moreover, by drawing on cultural legacies of commemoration, hNPOs found it easier to demonstrate the neutral and apolitical nature of their events, demonstrating not just their organisational strength but the strength of Russian society (i.e. aligning with the nationalistic discourse promoted by the Putin administration). Respondents specifically emphasised that they were then able to use this for more regular engagement with 'radio programs' (2.1b), 'advertised on [local] TV' (2.2a), 'publishing magazines' (2.3a), and 'Facebook and other social media' (2.2a) to communicate their activities and how well they did themraising awareness of themselves and their organisational strength beyond one-off-events. This can also be seen as an indication that organisations have begun to move beyond patronage, personalism, and tight group boundaries that have characterised post-Soviet Russian NPOs to date (Spencer 2011; Spencer and Skalaban 2018).

Reflecting on their rationale for engaging in raising awareness (both for their cause and themselves), hNPOs in this study also saw their engagement in humanitarian and charitable assistance as helping the profile of their organisations in addition to helping their constituencies. Such activities by hNPOs, be they focused on helping children or assisting drug users, focused on the collection and distribution of a wider range of donated goods or gifts including 'clothes' (2.3a; 1.2a), 'toys' (1.2a; 1.4a) 'diapers and wipes' (1.4a), or 'books, furniture and appliances' (1.2a). Organisations would also often link humanitarian engagement with their awareness-raising activities. In particular, they would use specific events to 'announce that we need these products, [so that] people [could] bring them' (1.4a). Two hNPOs in our study, both engaging with children with cancer, were also able to leverage this activity into 'raising money' (1.4a, 2.2a), in both cases for the treatment of individual children. However, other hNPOs in our study, in particular, those dealing with traditionally more contested issues (RivkinFish 2017; Titterton 2006) such as drug users, saw attempts at leveraging humanitarian engagements into raising money as 'wasting our energy' (1.5b, 2.5b) because drug addiction and use is not yet seen as a 'general [accepted] humanitarian issues, [that] society is (...) willing to fund' (2.1b).

Given the lack of philanthropic activities in the Soviet Union and persistently low levels of charitable donations since its disintegration (CAF Russia 2014), the ability of some groups to solicit donations (in-kind or monetary) is indicative of organisational strength that has thus far been considered lacking. This also allowed groups to engage with the wider public (Owen 2015; Owen and Bindman 2017; Tysiachniouk et al. 2018), countering the persistent negative connotation of NPOs in public discourse (Moser 
and Skripchenko 2018). This indicates positive spillovers from small 'p' political activity. However, this outreach falls into in what is perceived as politically safe or apolitical areas such as 'the disabled, animal welfare or environmental issues ${ }^{3}$ (2.1b) or activity which resonates with the traditional Christian-Orthodox cultural values of helping the needy (e.g. children with terminal illnesses). Evidence of outreach that went beyond this was not evident in this study.

\section{Conclusion}

In this paper, we set out to examine Russian civil society and NPOs through an activity-based lens. We asked specifically, how do NPOs in hybrid regimes use day-to-day activities and their small 'p' political power that results from them to influence how policy is deployed in their immediate environment. We sought to identify the organisational strength of NPOs that are associated with day-to-day activities and how and whether this creates spillovers, improving governance arrangements [for example, changing practices (small p politics) or changing governance arrangements (large $\mathrm{P}$ politics)]. Our insights provide a more positive story about Russian NPOs dovetailing recent observations made by others (Bogdanova et al. 2018). We highlight how regulatory changes aimed at establishing control over NPOs specifically through provision of resources (Daucé 2015; Krasnopolskaya et al. 2015; Moser and Skripchenko 2018; Robertson 2009; Salamon et al. 2015; Tarasenko 2018) have actually resulted in NPOs and the state working together in collaborative partnerships. Although discourse on organisational autonomy was largely missing from this study, organisations in this study were able to leverage their organising abilities (organisational strength) to work with and in some case for the state enabling to raise issues and change practices improving the life of their constituencies. Hence, the organisational strength of NPO provided them with political opportunities not only to make small changes from within, such as changing work practices within state-run service providers (Owen 2015; Owen and Bindman 2017) but also built ties with state authorities which can, as others observed, help buffer

\footnotetext{
3 The authors would like to note that this respondent's comment is their own viewpoint. For many respondents, environmental issues could include campaigning to stop environmental degradation but also weekly litter picking or maintain public flowerbeds. This respondent was referring to the latter types of activities which tend to less oppositional to state authorities. However, academic and research focus on Russia's environmental movement tends to be on campaigning organisations, which are engaging in activities that are considered political or more controversial (Yanitsky 2012). Thus, environmental organisations have been the target of state interventions with some of the most prominent, including Dront and Baikal Wave, closing their doors as a result of government harassment (HRW 2017).
}

against arbitrary institutional behaviour (Dieleman and Boddewyn 2011; Ljubownikow and Crotty 2017). As a result, these hNPOs at least had manoeuvred themselves into a position from which they can now influence the lives of their constituencies, although their ultimate goal might not be democratisation, as the traditional conceptualisation of civil society assumes (Diamond 1999).

Our data also showed that hNPOs encouraged the public to engage in their activities and were able to, as also observed by others (Fröhlich and Jacobsson 2019), use public events to mobilise support beyond their core service work (mainly humanitarian in nature), and thus more actively draw in outsiders to do civil society (Vorbrugg 2015). In the longer run, this sort of activity might mean that the Russian public no longer views NPOs and other civil society agents as untrustworthy (Chebankova 2009; Crotty 2006; Henderson 2002; Henry 2006; Mendelson and Gerber 2007; Spencer 2011). Although organisations cannot demonstrate autonomy from the state by holding it to account or challenging it directly [i.e. being overtly political in a hybrid regime (Moser and Skripchenko 2018)], we highlighted that organisations had some autonomy over the activities they can engage in. This indicates that the Russian state clearly sees NPOs as having (social) relevance and value.

Our study of the Russian case also highlights that various factors (we illustrate some of the regulatory as well as cultural conditions) within hybrid regimes shape what can be seen as the operating space of NPOs. Thus, our paper also contributes to expanding our understanding of NPOs in hybrid regimes more generally. What the Russia experience illustrates is that civil society and its agents play an important role in the way in which hybrid regimes govern. However, the insight from the organisations in our study also suggests that NPOs in hybrid or authoritarian participatory regimes (Mainwaring 2012; Owen 2018; Xiaojun and Ge 2016) can deploy tactics and strategies to influence public policy deployment (i.e. practices and how governance happens) - if not public policy itself (i.e. governance arrangements). By using the very restrictions placed on them to 'control' civil society (be apolitical welfare service providers), organisations can use their organisational strength and arising relationships with state actors to exert influence. Our findings indicate that short of banning third sector organisations altogether, it is impossible to exclude their influence on public policy entirely.

Our conclusions need to be seen in light of the limitations of this study. A larger sample, a different methodological approach, different areas of NPO activity and different regions may have provided other insights into the activities of Russian civil society organisations. Our focus on one sector in two regions also means that future research will need to focus on a more detailed exploration of organisational activities in less industrial regions and within different NPO sectors, particularly as we already indicate that those 
hNPOs engage engaged in political or social stigma find engagement in some types of activities less worth their while. We would also suggest that future research in Russia might also take a more gendered focus (Lyytikäinen 2013; Salmenniemi 2005). Both women's rights and hNPOs are dominated by female leaders and seemed to have been successful at demonstrating organisational strength and 'managing' Russia's hybrid regime environment. Are NPOs led by men similarly successful? Future research will need to continue to be mindful that the Russian Federation spans a large geographic territory encompassing a myriad of cultural groupings that might affect the activities of NPOs. Furthermore, research will also need to look into other similar regimes to explore whether and the factors which influence whether NPOs are able to influence policy deployment to a greater or lesser extent than in the Russian Federation.

This notwithstanding, our paper extends an emerging understanding of how Russian NPOs and NPOs in hybrid regimes more generally exert influence despite the prevailing hostile environment created by a hybrid regime. Although hNPOs in our study succumbed to heteronomous power (Riley and Fernández 2014) and generally aligned their activities with what they perceive as explicit or implicit requirements of the state (Moser and Skripchenko 2018), they were still able to demonstrate organisational strength. Consequently, we find vibrancy at the organisational level with NPOs affecting social change through their core service-providing activities and influencing public policy deployment. For them, being able to make small changes to the life of their constituencies from within the system is proving a more successful approach than the more confrontational and governance rearrangement focus of Russia civil society agents in the past.

Funding Funding was provided by British Academy (Grant Number SG111936).

Open Access This article is licensed under a Creative Commons Attribution 4.0 International License, which permits use, sharing, adaptation, distribution and reproduction in any medium or format, as long as you give appropriate credit to the original author(s) and the source, provide a link to the Creative Commons licence, and indicate if changes were made. The images or other third party material in this article are included in the article's Creative Commons licence, unless indicated otherwise in a credit line to the material. If material is not included in the article's Creative Commons licence and your intended use is not permitted by statutory regulation or exceeds the permitted use, you will need to obtain permission directly from the copyright holder. To view a copy of this licence, visit http://creativecommons. org/licenses/by/4.0/.

\section{Appendix}

\section{Appendix A: Overview of Participating Organisations}

\section{See Table 1.}

Table 1 Overview of participating organisations

\begin{tabular}{lll}
\hline Code & Interviewee(s) & Organisational Focus \\
\hline $\begin{array}{l}\text { Organisations in Samara (Region 1) } \\
\text { Organisation 1.1: }\end{array}$ & Director/Founder & Disability \\
Interview 1a & & \\
Interview 1b & Managing Director & At-Risk Children \\
Organisation 1.2: Interview 2a & & Palliative care - Cancer \\
Interview 2b & Managing Director & \\
Organisation 1.3: Interview 3a & & Childhood Cancer \\
Interview 3b & Director/Founder & \\
Organisation 1.4: Interview 4a & & HIV/AIDS prevention \\
Interview 4b & Director/Founder & \\
Organisation 1.5: Interview 5a & & Action on Drug Addiction \\
Interview 5b & & \\
$\begin{array}{l}\text { Organisations in Perm (Region 2) } \\
\text { Organisation 2.1: Interview 1a }\end{array}$ & Managing Director \\
$\begin{array}{l}\text { Interview 1b } \\
\text { Organisation 2.2: Interview 2a }\end{array}$ & Managing Director & Childhood Cancer \\
Organisation 2.3: Interview 3a & Director/Founder & At-Risk Children \\
Interview 3b & & \\
\hline
\end{tabular}


Table 1 continued

\begin{tabular}{lll}
\hline Code & Interviewee(s) & Organisational Focus \\
\hline Organisation 2.4: Interview 4a & $\begin{array}{l}\text { Managing Director } \\
\text { Deputy Director/Founder }\end{array}$ & At-Risk Children including homeless \\
Interview 4b & & \\
Interview 4c & & \\
Interview 4d & HIV/AIDS prevention \\
Organisation 2.5: Interview 5a & $\begin{array}{l}\text { Director/Founder } \\
\text { Interview 5b }\end{array}$ & Chief Operating Officer \\
Organisation 2.6: Interview 6a & Director/Founder & Palliative Care - Cancer \\
Organisation 2.7: Interview 7a & Managing Director & Disability \\
Interview 7b & & \\
\hline
\end{tabular}

\section{References}

Almog-Bar, M., \& Schmid, H. (2014). Advocacy activities of nonprofit human service organizations: A critical review. Nonprofit and Voluntary Sector Quarterly, 43(1), 11-35.

Anheier, H. K., Lang, M., \& Toepler, S. (2019). Civil society in times of change: Shrinking, changing and expanding spaces and the need for new regulatory approaches. Economics: The OpenAccess, Open-Assessment E-Journal, 13, 1-27.

Benevolenski, V. B., \& Toepler, S. (2017). Modernising social service delivery in Russia: Evolving government support for non-profit organisations. Development in Practice, 27(1), 64-76.

Berg-Nordlie, M., \& Bolshakov, N. (2018). The critical movement against the 2010-2012 education reform in Russia: Networks, Organisations and Parties. Europe-Asia Studies, 70(4), 666-684.

Bloodgood, E. A., Tremblay-Boire, J., \& Prakash, A. (2014). National styles of NGO regulation. Non-profit and Voluntary Sector Quarterly, 43(4), 716-736.

Bogdanova, E., Cook, L. J., \& Kulmala, M. (2018). The carrot or the stick? Constraints and opportunities of Russia's CSO Policy. Europe-Asia Studies, 70(4), 501-513.

CAF Russia. (2014). Russia Giving: Research on Individual Giving in Russia (p. 23). Moscow: Charities Aid Foundation Russia. Retrieved from 10 December 2014. https://www.cafonline.org/ PDF/CAF_Russia_GivingReport_ENG_final_web.pdf.

Chebankova, E. (2009). The evolution of Russia's Civil Society under Vladimir Putin: A cause for concern or grounds for optimism? Perspectives on European Politics and Society, 10(3), 394-415.

Cohen, J. L., \& Arato, A. (1994). Civil society and political theory. London: MIT Press.

Cook, L. (2007). Negotiating welfare in postcommunist states. Comparative Politics, 40(1), 41-62.

Crotty, J. (2006). Reshaping the Hourglass? The environmental movement and civil society development in the Russian Federation. Organization Studies, 27(9), 1319-1338.

Crotty, J., Hall, S. M., \& Ljubownikow, S. (2014). Post-Soviet Civil Society Development in the Russian Federation: The Impact of the NGO Law. Europe-Asia Studies, 66(8), 1253-1269.

Danilova, N. (2016). The Politics of War Commemoration in the UK and Russia. New York: Springer.

Daucé, F. (2015). The Duality of Coercion in Russia: Cracking down on "Foreign Agents". Demokratizatsiya, 23(1), 57-75.

de Vaus, D. (2001). Research design in social research. London: SAGE.

Diamond, L. J. (1999). Developing democracy: Toward consolidation. Baltimore: JHU Press.

Diamond, L. J. (2002). Thinking about hybrid regimes. Journal of Democracy, 13(2), 21-35.
Dieleman, M., \& Boddewyn, J. J. (2011). Using organization structure to buffer political ties in emerging markets: A case study. Organization Studies, 33(1), 71-95.

Federal State Statistics Service. (2010). Всероссийская перепись населения 2010 года. Russian National Census of 2010. Retrieved from 1 July 2011 http://www.perepis-2010.ru/.

Flikke, G. (2018). Conflicting opportunities or patronal politics? Restrictive NGO Legislation in Russia 2012-2015. Europe-Asia Studies, 70(4), 564-590.

Fröhlich, C. (2012). Civil society and the state intertwined: The case of disability NGOs in Russia. East European Politics, 28(4), 371-389.

Fröhlich, C., \& Jacobsson, K. (2019). Performing resistance: Liminality, infrapolitics, and spatial contestation in contemporary Russia. Antipode, 51(4), 1146-1165.

Fröhlich, C., \& Skokova, Y. (2020). Two for One: Public welfare and regime legitimacy through state funding for CSOs in Russia. VOLUNTAS: International Journal of Voluntary and Non-profit Organizations, 31(4), 698-709.

Gioia, D. A., Corley, K. G., \& Hamilton, A. L. (2013). Seeking qualitative rigor in inductive research: Notes on the Gioia methodology. Organizational Research Methods, 16(1), 15-31.

Guo, C., \& Zhang, Z. (2014). Understanding Non-profit advocacy in non-western settings: A framework and empirical evidence from Singapore. VOLUNTAS: International Journal of Voluntary and Non-profit Organizations, 25(5), 1151-1174.

Hale, H. (2010). Eurasian polities as hybrid regimes: The case of Putin's Russia. Journal of Eurasian Studies, 1(1), 33-41.

Hemment, J. (2004). The riddle of the third sector: Civil Society, International Aid, and NGOs in Russia. Anthropological Quarterly, 77(2), 215-241.

Hemment, J. (2007). Empowering Women in Russia. Bloomington: Indiana University Press. Retrieved from 17 January $2018 \mathrm{http} / / /$ www.iupress.indiana.edu/isbn/9780253218919.

Henderson, S. L. (2002). Selling Civil Society: Western Aid and the Nongovernmental Organization Sector in Russia. Comparative Political Studies, 35(2), 139-167.

Henderson, S.L. (2008). Shaping Civic Advocacy: International and Domestic Policies Towards Russia's NGO Sector. Retrieved from 5 June 2009 http://evans.washington.edu/files/Henderso nAdvocacyChapter.pdf.

Henry, L. (2006). Shaping Social Activism in Post-Soviet Russia: Leadership, organizational diversity, and innovation. Post-Soviet Affairs, 22(2), 99-124.

Henry, L. (2012). Complaint-making as political participation in contemporary Russia. Communist and Post-Communist Studies, 45(3-4), 243-254. 
Henry, L., \& Sundstrom, L. M. (2006). Introduction. In A. Evans, L. Henry, \& L. M. Sundstrom (Eds.), Russian Civil Society: A critical assessment (pp. 3-8). London: M.E. Sharpe.

Howard, M. M. (2002). Postcommunist civil society in comparative perspective. Demokratizatsiya, 10(3), 285-305.

HRW. (2017). Russia: 'Year of Ecology' a Sham. Human Rights Watch. Retrieved from 30 April 2020 https://www.hrw.org/ news/2017/11/21/russia-year-ecology-sham.

Jakobson, L., \& Sanovich, S. (2010). The changing models of the Russian Third Sector: Import substitution phase. Journal of Civil Society, 6(3), 279-300.

Javeline, D., \& Lindemann-Komarova, S. (2010). A balanced assessment of Russian Civil Society. Journal of International Affairs, 63(2), 171-188.

Johnson, J. E., \& Saarinen, A. (2011). Assessing civil society in Putin's Russia: The plight of women's crisis centers. Communist and Post-Communist Studies, 44(1), 41-52.

Karl, T. L. (1995). The hybrid regimes of Central America. Journal of Democracy, 6(3), 72-86.

Krasnopolskaya, I., Skokova, Y., \& Pape, U. (2015). Governmentnon-profit relations in Russia's Regions: An exploratory analysis. VOLUNTAS: International Journal of Voluntary and Nonprofit Organizations, 26(6), 2238-2266.

Kulmala, M. (2016). Post-Soviet "Political"? "Social" and "Political" in the Work of Russian Socially Oriented CSOs. Demokratizatsiya; Washington, 24(2), 199-224.

Kulmala, M., \& Tarasenko, A. (2016). Interest representation and social policy making: Russian Veterans' organisations as brokers between the state and society. Europe-Asia Studies, 68(1), $138-163$.

Linz, J. J., \& Stepan, A. (1996). Towards consolidated democracies. Journal of Democracy, 7(2), 14-33.

Linz, J. J., Stepan, A., \& Gunther, R. (1995). Democratic transition and consolidation in Southern Europe, with Reflection on Latin America and Eastern Europe. In R. Gunther, H.-J. Puhle, \& P. N. Diamandouros (Eds.), The politics of democratic consolidation: Southern Europe in Comparative Prespective (pp. 77-123). Baltimore: The Johns Hopkins University Press.

Ljubownikow, S., \& Crotty, J. (2014). Civil Society in a Transitional Context: The Response of Health and Educational NGOs to Legislative Changes in Russia's Industrialized Regions. Nonprofit and Voluntary Sector Quarterly, 43(4), 759-776.

Ljubownikow, S., \& Crotty, J. (2016). Non-profit influence on public policy exploring non-profit advocacy in Russia. Non-profit and Voluntary Sector Quarterly, 45(2), 314-332.

Ljubownikow, S., \& Crotty, J. (2017). Managing boundaries: The role of non-profit organisations in Russia's managed democracy. Sociology, 51(5), 940-956.

Ljubownikow, S., Crotty, J., \& Rodgers, P. (2013). The State and Civil Society in Post-Soviet Russia: The development of a Russian Style Civil Society. Progress in Development Studies, 13(2), 153-166.

Lyytikäinen, L. (2013). Gendered and classed activist identity in the Russian oppositional youth movement: Gendered and classed activist identity. The Sociological Review, 61(3), 499-524.

Mainwaring, S. (2012). From representative democracy to participatory competitive authoritarianism: Hugo Chávez and Venezuelan Politics. Perspectives on Politics, 10(04), 955-967.

Mendelson, S. E., \& Gerber, T. (2007). Activist culture and transnational diffusion: Social Marketing and Human Rights Groups in Russia. Post-Soviet Affairs, 23(1), 50-75.

Miles, M. B., \& Huberman, A. M. (1999). Qualitative data analysis (2nd ed.). London: Sage.

Moser, E., \& Skripchenko, A. (2018). Russian NGOs and Their Struggle for Legitimacy in the Face of the 'Foreign Agents'
Law: Surviving in small ecologies. Europe-Asia Studies, 70(4), 591-614.

Owen, C. (2015). "Consentful contention" in a corporate state: human rights activists and public monitoring commissions in Russia. East European Politics, 31(3), 274-293.

Owen, C. (2018). State Transformation and Authoritarian Governance: The Emergence of Participatory Authoritarianism? The Foreign Policy Centre. Retrieved from 6 March 2019 https://fpc. org.uk/state-transformation-and-authoritarian-governance-theemergence-of-participatory-authoritarianism/.

Owen, C., \& Bindman, E. (2017). Civic participation in a hybrid regime: Limited pluralism in policymaking and delivery in contemporary Russia. Government and Opposition, 54, 1-23.

Pape, U. (2018). Framing the epidemic: NGOs and the fight against HIV/AIDS in Russia. Russian Politics, 3(4), 486-512.

Richter, J., \& Hatch, W. F. (2013). Organizing civil society in Russia and China: A comparative approach. International Journal of Politics, Culture, and Society, 26(4), 323-347.

Riley, D., \& Fernández, J. J. (2014). Beyond strong and weak: Rethinking Postdictatorship Civil Societies. American Journal of Sociology, 120(2), 432-503.

Rivkin-Fish, M. (2017). Legacies of 1917 in Contemporary Russian Public Health: Addiction, HIV, and Abortion. American Journal of Public Health, 107(11), 1731-1735.

Robertson, G. B. (2009). Managing society: Protest, Civil Society, and Regime in Putin's Russia. Slavic Review, 68(3), 528-547.

Salamon, L. M., Benevolenski, V. B., \& Jakobson, L. I. (2015). Penetrating the Dual Realities of Government-Non-profit Relations in Russia. VOLUNTAS: International Journal of Voluntary and Non-profit Organizations, 26(6), 2178-2214.

Salmenniemi, S. (2005). Civic Activity-Feminine Activity?: Gender, Civil Society and Citizenship in Post-Soviet Russia. Sociology, 39(4), 735-753.

Shapovalova, Y. (2015). Modernizing State Support of Nonprofit Service Provision: The Case of Kyrgyzstan. VOLUNTAS: International Journal of Voluntary and Non-profit Organizations, 26, 1-16.

Siggelkow, N. (2007). Persuasion with case studies. Academy of Management Journal, 50(1), 20-24.

Sivunen, A., \& Putnam, L. L. (2020). The dialectics of spatial performances: The interplay of tensions in activity-based organizing. Human Relations, 73(8), 1129-1156.

Skokova, Y. (2017). Russia: Civil Society Sector Divided. In 2016 Report on the State of Civil Society in the EU and Russia (pp. 126-145). Berlin: EU-Russia Civil Society Forum. Retrieved from 13 September 2019 https://publications.hse.ru/mirror/pubs/ share/folder/jnv9d812cn/direct/205928495.

Skokova, Y., Pape, U., \& Krasnopolskaya, I. (2018). The Non-profit Sector in Today's Russia: Between Confrontation and Cooptation. Europe-Asia Studies, 70(4), 531-563.

Spencer, S. (2011). Culture as structure in Emerging Civic Organizations in Russia. Non-profit and Voluntary Sector Quarterly, 40(6), 1073-1091.

Spencer, S., \& Skalaban, I. A. (2018). Organizational culture in Civic Associations in Russia. VOLUNTAS: International Journal of Voluntary and Non-profit Organizations, 29(5), 1080-1097.

Spires, A. J. (2011). Contingent Symbiosis and Civil Society in an Authoritarian State: Understanding the Survival of China's Grassroots NGOs. American Journal of Sociology, 117(1), 1-45.

Tarasenko, A. (2018). Russian Non-Profit Organisations in Service Delivery: Neoliberal and Statist Social Policy Principles Intertwined. Europe-Asia Studies, 70(4), 514-530.

Tarrow, S. (1989). Struggle, politics, and reform: Collective action, social movements and cycles of protest. New York: Center for International Studies, Cornell University. 
Thomson, K. (2006). Disability organizations in the regions. In A. Evans, L. Henry, \& L. M. Sundstrom (Eds.), Russian Civil Society: A critical assessment (pp. 229-243). London: M.E. Sharpe.

Titterton, M. (2006). Social policy in a cold climate: Health and Social Welfare in Russia. Social Policy \& Administration, 40(1), 88-103.

Tysiachniouk, M., Tulaeva, S., \& Henry, L. (2018). Civil society under the Law 'On Foreign Agents': NGO strategies and network transformation. Europe-Asia Studies, 70(4), 615-637.

Vetta, T. (2018). Democracy struggles: NGOs and the Politics of Aid in Serbia. New York: Berghahn Books.

Vorbrugg, A. (2015). Governing through civil society? The making of a post-Soviet political subject in Ukraine. Environment and Planning D: Society and Space, 33(1), 136-153.

Whittington, R. (2006). Completing the practice turn in strategy research. Organization Studies, 27(5), 613-634.
Wigell, M. (2008). Mapping 'Hybrid Regimes': Regime types and concepts in comparative politics. Democratization, 15(2), 230.

Wilde, G., Zimmer, A., Obuch, K., \& Sandhaus, J. (2018). Civil Society and Gender Relations in Authoritarian and Hybrid Regimes: New Theoretical Approaches and Empirical Case Studies. Leverkusen-Opladen, Germany: Verlag Barbara Budrich. Retrieved from 16 April 2019 http://ebookcentral. proquest.com/lib/sheffield/detail.action?docID $=5570986$.

Xiaojun, Y., \& Ge, X. (2016). Participatory policy making under authoritarianism: the pathways of local budgetary reform in the People's Republic of China. Policy \& Politics, 44(2), 215-234.

Yanitsky, O. (2012). From nature protection to politics: The Russian Environmental Movement 1960-2010. Environmental Politics, 21(6), 922-940.

Publisher's Note Springer Nature remains neutral with regard to jurisdictional claims in published maps and institutional affiliations. 